\title{
Brief retrospection on Hungarian school atlases
}

\author{
István Klinghammer, José Jesús Reyes Nuñez ${ }^{\mathrm{b}}$ \\ ${ }^{a}$ Department of Cartography and Geoinformatics, Faculty of Informatics, Eötvös Loránd University, Budapest, \\ Hungary; klinghammer@ludens.elte.hu \\ ${ }^{b}$ Department of Cartography and Geoinformatics, Faculty of Informatics, Eötvös Loránd University, Budapest, Hungary; \\ jesusreyes@caesar.elte.hu
}

\begin{abstract}
The first part of this article is dedicated to the history of Hungarian school atlases to the end of the 1st World War. Although the first maps included in a Hungarian textbook were probably made in 1751, the publication of atlases for schools is dated almost 50 years later, when professor Ézsáiás Budai created his "New School Atlas for elementary pupils" in 1800. This was followed by a long period of 90 years, when the school atlases were mostly translations and adaptations of foreign atlases, the majority of which were made in German-speaking countries. In those years, a school atlas made by a Hungarian astronomer, Antal Vállas, should be highlighted as a prominent independent piece of work. In 1890, a talented cartographer, Manó Kogutowicz founded the Hungarian Geographical Institute, which was the institution responsible for producing school atlases for the different types of schools in Hungary. The professional quality of the school atlases published by his institute was also recognized beyond the Hungarian borders by prizes won in international exhibitions. Kogutowicz laid the foundations of the current Hungarian school cartography: this statement is confirmed in the second part of this article, when three of his school atlases are presented in more detail to give examples of how the pupils were introduced to the basic cartographic and astronomic concepts as well as how different innovative solutions were used on the maps.
\end{abstract}

Keywords: School cartography, school atlas, Kogutowicz, Hungarian Geographical Institute

\section{Brief history to the 1st World War}

The beginnings of Hungarian school cartography can be dated to 1781, when the book entitled „Introductio in geographiam Hungariae antiqui et medii aevi" was published with twelve historical maps. Its author was a Luther-an pastor, János Tomka-Szászky, who probably made the maps in Bratislava some years earlier, in 1751 (Figure 1). Another author of the same period was István Losonczi with his "Triple Mirror of Hungary" that was a book on the history and geography of Hungary and Transylvania. The first edition of this work appeared in 1770 with two inset maps without any reference to their author; however, based on the similar characteristics of both maps, it can be supposed that they were made by the same person.

The first Hungarian school atlas was printed in Debrecen in 1800 , a city placed in the East region of the country at a distance of about 200 kilometres from Budapest. Its author was professor Ézsáiás Budai, who counted with the collaboration of some of his "togatus" students to make the maps from 1797. The title of the atlas was "New School Atlas for elementary pupils" and only had twelve pages with the following maps: Earth globe, Europe, Asia, Africa, North America, South America, Spain, France, Italy, Germany, Poland and Hungary. A curious detail is that Hungary was not represented as a country map, but on a regional map. The country was placed to the top left corner of the page, because the map also contained the city of Kiev, Crimean Peninsula on the East as well as the city of Thessaloniki on the South.

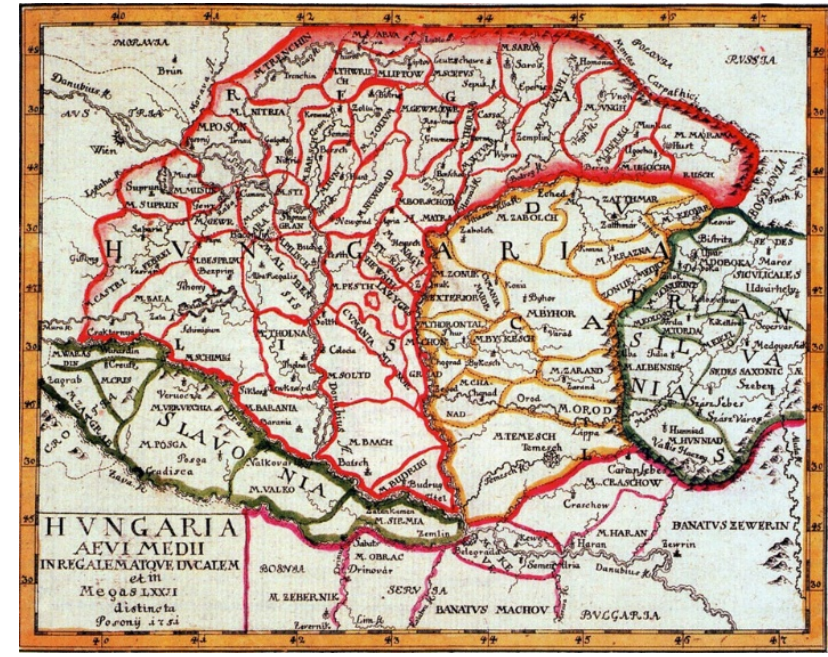

Fig. 1. One of the maps made by Tomka-Szászky: "Hungary in the Middle Ages" (Source: Peragovics, 2013)

In the immediate years after this work, only a small, tenpage school atlas was published in Hungary in 1817. From today's perspective, its title sounds interesting: "Hungarian National Atlas". Its author was a foreignborn soldier, Eduárd Greipel.

Only almost 30 years later, in 1845 a new school atlas was made by a talented Hungarian astronomer (Antal Vállas), which was printed in Vienna with the title "New hand- and school atlas with geographical and statistical notes. For newspapers readers and pupils". It contained 18 pages, representing the Earth divided into two hemispheres, the continents, the European countries and 
Hungary with two inset maps of Pest-Buda and Fiume (currently Rijeka in Croatia). Vállas was the first to use a Hungarian nomenclature on the maps; he also added statistical data to enrich and diversify the content. Perhaps he worked with French sources to draw his maps, because Paris is the prime meridian on them.

During the period between 1845 and 1890, foreign school atlases were adapted and translated for use in Hungarian schools. The majority of them were from Germanspeaking countries. This situation began to change in 1891, when a School Atlas Commission was set up within the Hungarian Geographical Society. In their meeting in May of the same year, the commission addressed a document for the Ministry of Education describing the actual situation of school cartography in the country and emphasizing the erroneous and obsolete wall maps used in the Hungarian schools, but without mentioning the lack of Hungarian school atlases.

In 1887, an experienced Hungarian cartographer, Manó Kogutowicz (Figure 2) published a small school atlas ("Small Atlas with a county map for 3rd grade pupils of Elementary Schools"). It had only five pages containing maps of Budapest, surrounds of Budapest, Pest County and an administrative map of Hungary. This was completed with new maps in the following editions and the number of pages grew up to 13 in a period of 10 years.

In 1890, Manó Kogutowicz convinced the Ministry of Education of the pressing national need of a Hungarian cartographic institution. Kogutowicz established the Hungarian Geographical Institute in the same year with the personal support of the minister, Albin Csáky. During the first two years, the institute was a subsidiary of the Hölzel Company (based in Vienna). It became an independent firm under the name Kogutowicz \& Co. in 1892; however, Kogutowicz continued the collaboration with Hölzel. One of the results of this partnership was a Hungarian atlas using some maps of the school atlases published by Hölzel in Vienna. This atlas was entitled "Atlas for lower and up-per classes of Elementary Schools", which contained 16 pages and was published in 1896. A new and original map was also included, which was planned and drawn by Kogutowicz: the two-page physical map of Hungary. According to Klinghammer (2002), it was the first physical map of the country totally made by a Hungarian cartographer after the era of Absolutism in Hungary (1849-1867).

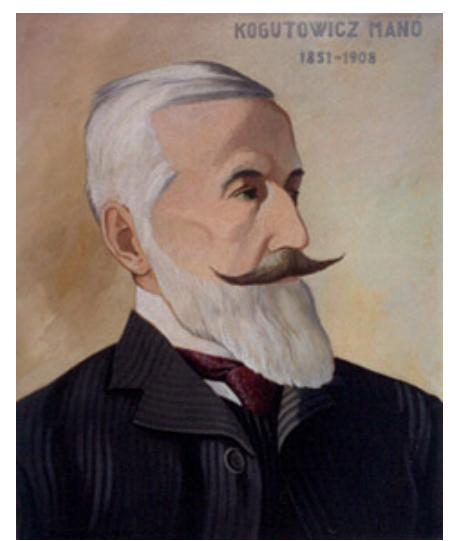

Fig. 2. Portrait of Manó Kogutowicz (1851-1908)

In the meanwhile, in the city of Debrecen, a book publisher, Gyula Kozma made the Hungarian versions of the contemporary Diercke Atlases from Germany. The first one was the "General Geographical Atlas" in 1889, which was followed by the "School Atlas" and the "Systematic Geographical Atlas", both published in 1890 (Figure 3).

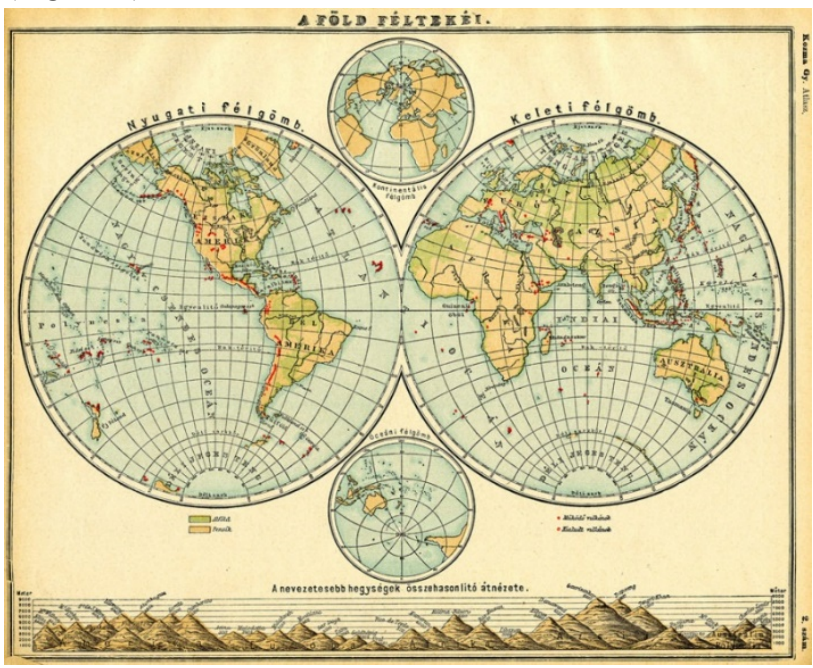

Fig. 3. World map from the "Systematic Geographical Atlas" of Gyula Kozma (1890)

During these years, Kogutowicz also made maps of continents as well as county and country maps of Hungary. He used these maps in school atlases published for different types of schools in the Hungarian Educational System, e.g. the series entitled "Small Atlas with a county map" for the Elementary Schools and the "Geographical School Atlas" for Higher Elementary Schools.

Years earlier, Kogutowicz recognized the importance of the participation of scientists during the selection and edition of the content to be represented on a map. Following his conviction, he consolidated his company with the addition of specialists, including the most renowned Hungarian geographer in this period, Jenö Cholnoky. The first result of this collaboration was the "Geographical Atlas for Secondary Schools... with the collaboration of Jenő Cholnoky... planned and drawn by Manó Kogutowicz", which was published in 1900. The atlas included 36 maps and 4 inset maps. The majority of 
these maps were expressly made for this atlas and only some of them were adapted from foreign school maps. An innovative characteristic of this atlas was that it surpassed the traditional brief presentation of basic map concepts of former atlases by including astronomical and mathematical concepts for the first time in Hungary. It was also the first work that represented some statistical data on maritime traffic on a world map. Another acknowledged Hungarian geographer, Lajos Lóczy wrote about this atlas: "This is the first, totally original school atlas made in our homeland".

The content and printing quality of this atlas competed with the level of its German equivalents (the Kozenn, Diercke, Gaebler and Wettstein school atlases). It had numerous editions up to the 1910s, reaching to include 48 main maps and many inset maps.

Two maps should be highlighted due to their significance: the "Geological Map of Hungary" and the "Physical Map of Hungary", both of them at the scale of 1: 2.4 million. The thematic content of the geological map was compiled by Cholnoky. The landforms in the "Physical Map of Hungary" were represented using hachures in the first edition of the atlas. Later the map was changed and it became the first physical map in a Hungarian school at-las on which the relief was drawn using contour lines. Kogutowicz's son, Károly also worked on the later editions of this map (Figure 4).

The Hungarian geographical nomenclature used before this atlas was characterized by a total confusion provoked by arbitrary decisions taken to name the landforms. Jenö Cholnoky made a meritorious work to systematize and methodize the writing of geographic names of the Carpathian Basin, which became definitive on the "Physical Map of Hungary".

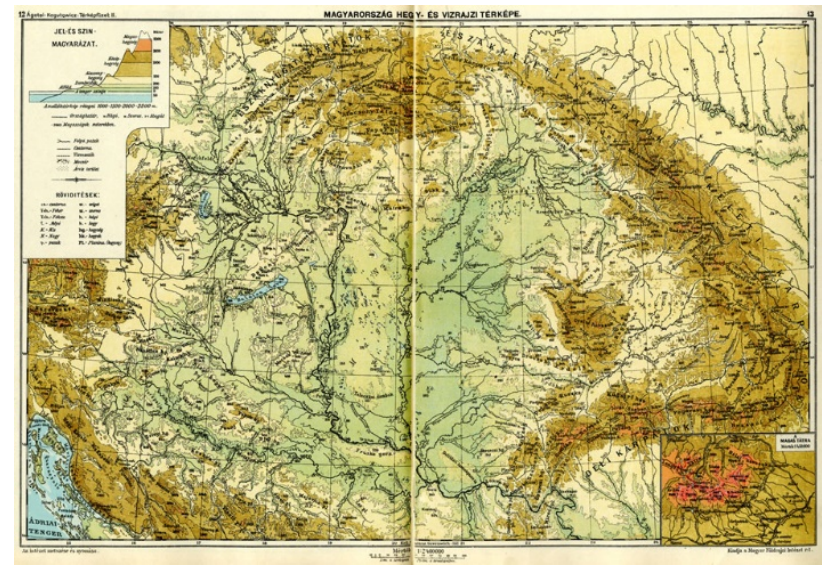

Fig. 4. Later version of the "Physical Map of Hungary" with contour lines from the "Map booklet for the 4th, 5th and 6th grades of Elementary Schools in Budapest" (1906)

In short, the publication of this atlas has been considered a milestone in the history of the Hungarian school cartography. After the extraordinary success of this atlas, Kogutowicz's company was contracted by the Ministry of Defence in 1900 to supply the military schools with atlases; this task was accomplished in the same year. In 1901, the company was reorganized as the Hungarian
Geographical Institute Co. The maps used in the school atlas also were the sources for the publication of the first Hungarian atlas, "Complete Atlas", specifically designed for the general public. The first edition was published in 1902 and had 68 main maps. It included new topics such as vege-tation and industrial production; Cholnoky collaborated in themes such as population and climatology (Márton, 2000-2002) while Károly Kogutowicz also collaborated as a young cartographer making maps for this atlas.

In 1906, Gyula Kozma in cooperation with other publisher, Lajos Toldi, printed a new school atlas under the title "Illustrated Geographical Atlas for the Elementary Schools". This work was also a Hungarian product, without any map adapted from foreign atlases, but citing Klinghammer (2002): "it was made with more good will than knowledge". Jenő Cholnoky expressed his opinion in the Bulletin edited by the Hungarian Geographical Society: "Its maps are inaccurate, erroneous and wrong, the pictures are tasteless and artless, they do not match the cartographic representation". The reason of this professional fiasco is that Kozma was neither a cartographer nor a geographer. He had no enough professional formation (nor collaborators with enough cartographic or geographic knowledge) to create a totally new atlas.

This regrettable incident re-affirmed the leading role played by Kogutowicz and his institute in the publication of cartographic materials for schools. In 1906, Kogutowicz made the "Map booklet for the 3rd grade of Elementary Schools in Budapest" (Figure 5) in collaboration with Béla Ágotai (school principal), which was followed by another similar workbook for 4th, 5th and 6th grades (Rúzsa, 2008).

Manó Kogutowicz deceased in 1908 and his son, Károly inherited the direction of the company. Manó Kogutowicz has been remembered as the most significant figure of the Hungarian Cartography in the final years of the 19 th and at the beginning of the 20th century. He was awarded the Great Medal of the Millennia by the Hungarian Government in 1896. In 1900, in the World Exhibition of Paris, his products received the Golden Medal, which brought him international recognition; he was also awarded a prize.

The number of publications grew to 160 by 1912 . The school atlases produced by Kogutowicz were used during the 1 st World War too. After the end of the war and the signing of the Treaty of Trianon, Hungary lost $72 \%$ of its territory and its frontiers changed considerably. The maps of Hungary in the school atlases needed to be re-worked (updated), but this is another chapter of the more recent history of Hungarian school cartography.

\section{Some examples on solutions used in old Hungarian school atlases}

Manó Kogutowicz laid the foundations of the Hungarian school cartographic traditions. His institute periodically re-edited their school atlases, even enriching its content with new maps, following the practice of those countries 
(like Germany or the United States) that counted with a longer tradition in this relatively young area of cartography. In the period between 1890 and 1918, he created atlases with appropriate content for the different grades and the different types of schools as well as for the different regions within the country. The content of three of his atlases are detailed below:

- Geographical School Atlas (1896): Basic map and astronomical concepts; Budapest; Budapest and surroundings; Hungary (physical map, 2 pages); Hungary (political map, 2 pages); Austro-Hungarian Empire (physical map); Austro-Hungarian Empire (political map); Europe (physical map); Europe (political map); Central Europe (Germany) /physical map/; Central Europe (Germany) /political map/; Balkans; Apennine Peninsula; France; Iberian Peninsula; Switzerland, Belgium, Netherlands, Luxembourg and Denmark; Great Britain and Ireland; Scandinavia; Russia; Asia; Near East; South and South East Asia; Palestine; Africa; America; United States, Central America and West Indies; Australia and Polynesia; The hemispheres; World map. (This list of maps comes from the 2 nd revised and extended edition of the atlas, 1900 [?])

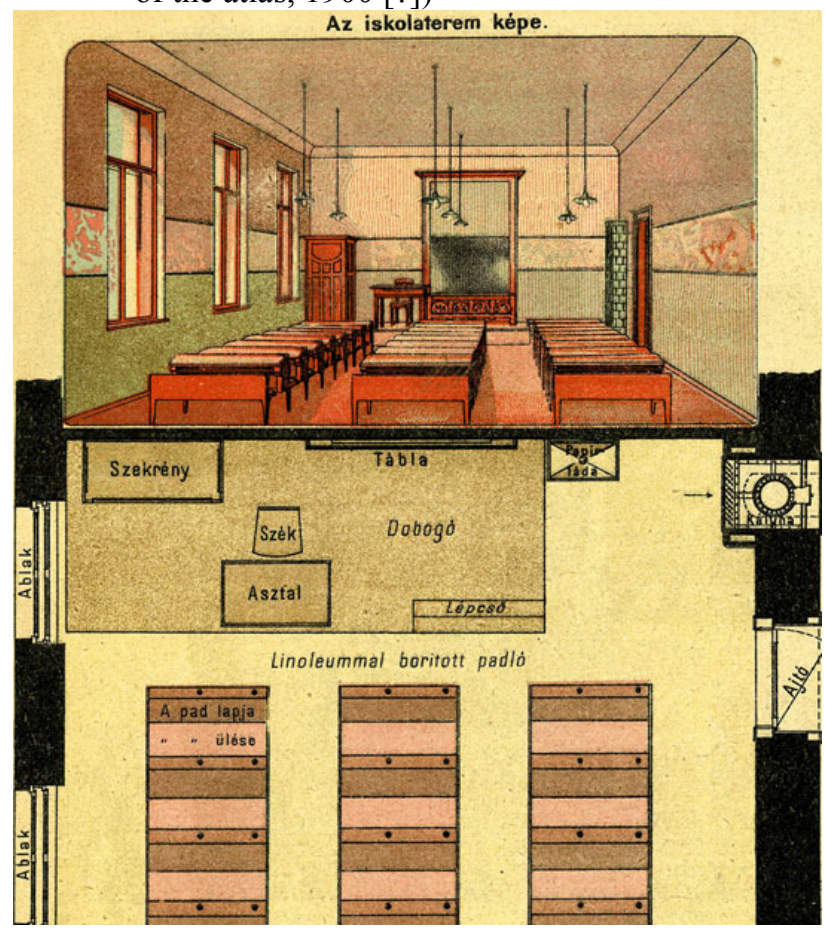

Fig. 5. Presenting the classroom and its top-plan view in the pages dedicated to the basic map concepts in the "Map booklet for the 3rd grade of Elementary Schools in Budapest" (extract)

- Map booklet for the 4th, 5th and 6th grades of Elementary Schools in Budapest (1906): Illustrations (pages 1 to 6); Budapest and surroundings (Visegrád); Basic map concepts (2 pages); Typical landscapes of Hungary (2 pages); Hungary (physical map); Hungary (political map); Fiume (current Rijeka, Croatia);
Hungary and Austria (political map); Europe (physical map); Europe (political map); Asia (physical map); Asia (political map); Africa (physical map); Africa (political map); America (physical map); America (political map); Australia; Hemispheres; basic astronomical concepts; world map of colonies and world traffic; illustrations (pages 31 to 36).

- Geographical Atlas with a county map for Elementary Schools (1909): Basic map concepts (3 pages); Buda-pest; Europe; Hungary (physical map); Hungary (political map, 2 pages); Hungary and Austria (political map); Asia; Africa; America; Australia; Hemispheres; Basic geographic concepts; county map in annex. This atlas was the successor of the series entitled "Small Atlas with a county map for Elementary Schools" started in 1896. This series had a special characteristic: the users received an annexed map of their county together with the atlas.

Many of the school atlases produced in German-speaking countries during the 19th century has been recognized by later specialists as scientifically very good quality products of this branch of cartography. Fortunately, by historical, political and societal reasons, the German influence was also felt in the new-born Hungarian school cartography. This influence can be divided into three cycles:

- First cycle: the positive impact was noticeable in the translation and adaptation of these products to the Hungarian language, as mentioned in the first part of this paper.

- Second cycle: Hungarian cartographers adapted some maps of the atlases made in Germanspeaking countries to include them in their own school atlases.

- Third cycle: Hungarian cartographers began to use the solutions developed by German-speaking cartographers in the maps fully made by themselves for Hungarian school atlases.

It can be affirmed that in general that extension and appearance of the school atlases printed in Hungary were much more modest than their counterparts in Germany and Austria; by the end of the 19th century, however, their quality was similar to those works that inspired them.

The influence exerted by the German-speaking school cartography on Hungarian school atlases can be resumed in three areas:

- The presentation of basic map and astronomical concepts

- The use of thematic inset maps to expand and diversify the information represented on main maps.

- The use of inset maps of their own country or region to help the pupils to understand better the territorial differences with other faraway countries or regions. 
The Hungarian school atlases produced from the middle of the 19th century included basic map concepts, and the atlases published by Kogutowicz's institute were not exceptions. He considered it important to dedicate at least a page to this topic in his atlases. Some basic concepts were presented in almost all atlases made by him (e.g. the bird's-eye and top-plan view of a house, the scale reduction). However, the more specific content and the number of pages for presenting the topic could be different according to the type of atlas and target school.

Other characteristic of his atlases was that in their consecutive editions the reader found innovative cartographic solutions. Kogutowicz did not avoid daring (and sometimes questionable) solutions like changing the colour for the representation of hydrographic elements from blue to black in the interest of more accurate printing (Figure 6). He did not merely adapt solutions from German-speaking cartographers, but consulted other internationally recognized sources too. One of the results of this openness to other cartographic schools was the adaptation of the hypsometric scale developed by the Bartholomew firm in those years for its use in the "Physical Map of Hungary".

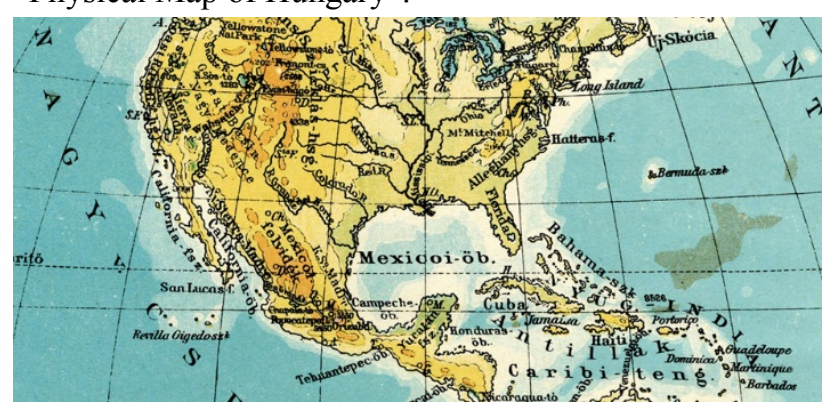

Fig. 6. Extract of the physical map of America with hydrography in black from the "Map booklet for the 4th, 5th and 6th grades of Elementary Schools in Budapest"

Kogutowicz also began to use consistently small inset maps on the corners of the main maps to represent additional themes. He included thematic maps as inset maps first in Hungary, representing topics such as ethnography, religions or precipitation (Figure 7). He was also the first cartographer to add a one-page thematic world map to his school atlases, which was included in the Geographical School Atlas of 1896; this map combined the representation of colonies (differentiating them by colours) and the maritime traffic (duration of journey in days between continents).

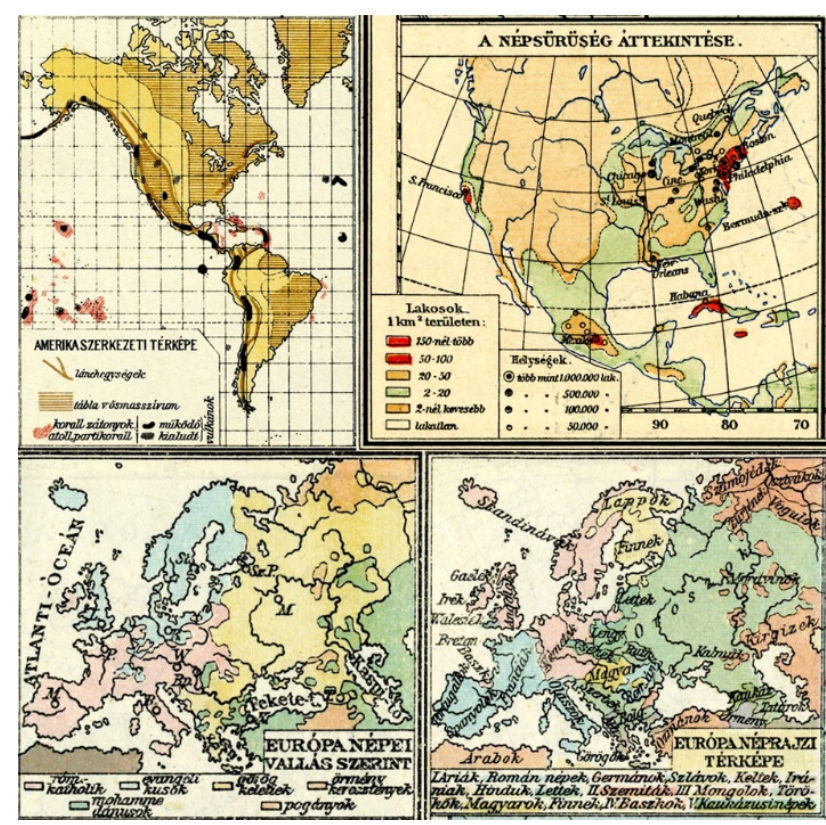

Fig. 7. Thematic inset maps from atlases published by Kogutowicz

Kogutowicz also took from German-speaking atlases a very easy and practical solution to point out the territorial differences between Hungary and countries or territories placed far away from Europe, as well as to highlight the distinctness caused by the scales of maps. A small inset map of Hungary was placed in a corner of the main map, using the same scale for both maps. In this way the pupils had an approximate idea of the real dimension of the territories represented on the main map in relation to the extension of their country at the same scale (Figure 8). This method was used very often in German-speaking school cartography, but was not widespread in other European countries and continents. This statement was confirmed after the study of the school atlases stored on the web-based David Rumsey Collection. Altogether 1648 images were found after a search with the "school" keyword in this period and 2033 images after looking for "school atlas". Only three European atlases (two German and one Swiss) were found, which used this solution. A similar search was also developed in the Library of the Department of Cartography and Geoinformatics at Eötvös Loránd University and only one school atlas was found: the "Atlas de Géographie Physique, Politique et Historique" published in Belgium in 1908, as seen in Figure 8.

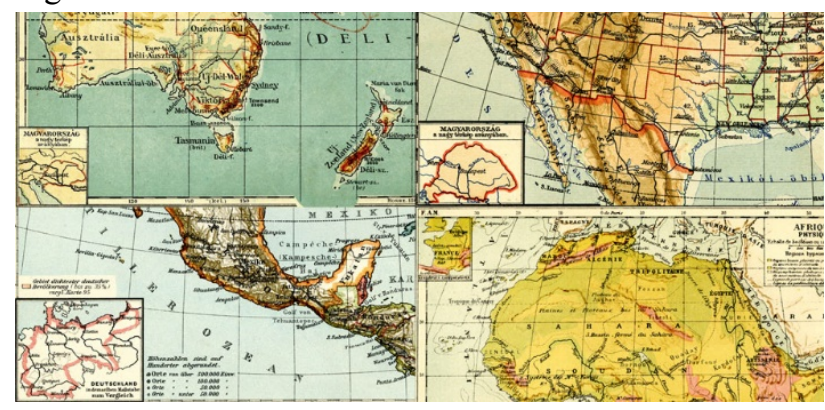

Fig. 8. Examples from Kogutowicz's atlases and foreign atlases. From top left: Australia (Kogutowicz's Geographical Atlas with a county map for Elementary Schools, 1909); United 
States, Central America and West Indias (Kogutowicz's Geographical School At-las, 2nd edition); United States, Mexico, Central America and West Indias (Debes' School Atlas, Germany, 1912) and Physical Africa (Alexis's Atlas of Physical, Political and Historical Geography, Belgium, 1908)

In his atlases the presentation of basic concepts is mainly based on illustrations, and he also used illustrations, photos, images, etc. on some interior pages of an atlas. He never used them within the maps, and the number of pages including illustrations was always much smaller than the number of pages with maps. At most, he placed im-ages beside a specific map on the same page, which can be observed on the two pages occupied by the political map of Hungary (Figure 9) in his Geographical School Atlas of 1896.

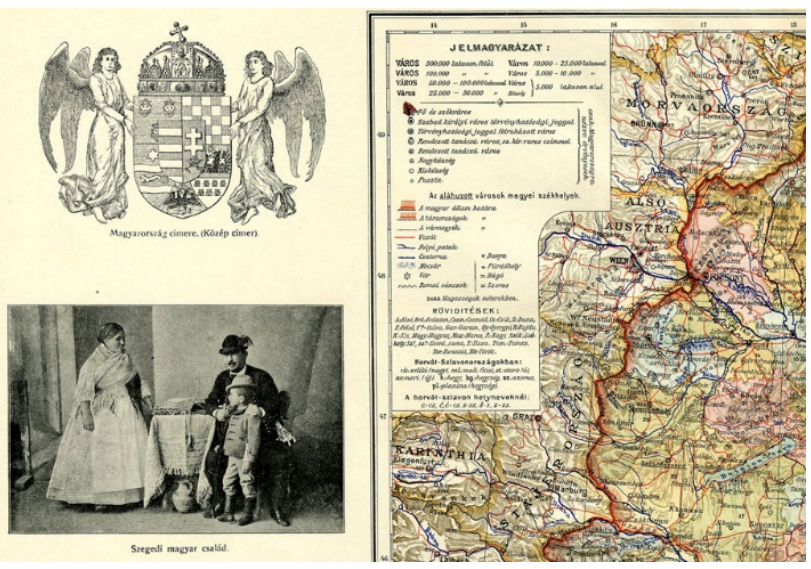

Fig. 9. Images with the political map of Hungary from the Geographical School Atlas (extract)

\section{Conclusions}

The authors had to limit this paper only to a brief background to the publication of geographical school atlases by the Hungarian Geographical Institute led by Manó Kogutowicz and his son, Károly. Their cartographic produc-tion was much wider, covering virtually the entire spectrum of materials for the supporting of teaching activities. Before he founded his institute, Manó Kogutowicz worked on a series of county wall maps of Hungary and completed a total of 35 by 1890. The Hungarian Geographical Institute also produced numerous wall maps for schools. The institute also supplied the Hungarian educational institutions with Earth globes. Márton (2008) specified that the diameter of the globes was 25.5 or $51 \mathrm{~cm}$ and some of them counted with some special details, as a small com-pass built into the footpad of a $25.5 \mathrm{~cm}$ globe made in 1910 . His first known globe is dated to 1896 , which had several editions (1897, 1901, 1905, 1908 and 1910). Finally, we cannot forget that Kogutowicz also published Historical atlases for the schools: one of the more popular ones was the "Historical Atlas for Secondary Schools" published in 1898.

Resuming, Kogutowicz Manó and his institute produced 37 physical wall maps (and about 24 wall maps of counties), 13 historical world maps and 10 Hungarian historical wall maps, 7 physical and 3 historical school atlases (with numerous editions), as well as a series of outline maps and globes for schools (Klinghammer, 2001). The Hungarian Geographical Institute remained in the history of the Hungarian school cartography as a pioneer leading institution, which marked the guidelines for those cartographers who follow or in the future will follow the educative activity developed by Kogutowicz and his colleagues.

\section{References}

Cartography Associates (2000-2016). David Rumsey Collection. http://www.davidrumsey.com/ Accessed 2 October 2016.

Klinghammer, I. (2001). A magyar térképészet a kezdetektől http://lazarus.elte.hu/hun/tanterv/c57/cikk1.pdf. Accessed 27 September 2016.

Klinghammer, I. (2002). A földrajzi szemléltetés korai története - Iskolai térképek, atlaszok, föld- és éggömbök az egykori magyar is-kolákban. Geodézia és Kartográfia, 54(12), 1-13.

Márton, M. (2002). Atlaszkartográfia. http://lazarus.elte.hu/hun/dolgozo/marton/atlasz/04b.ht m. Accessed 27 September 2016.

Márton, M. (2008). Kogutowicz Manó glóbuszai: Glóbusztérképek és állványra szerelt gömbök különböző http://slideplayer.hu/slide/2229480/. Accessed 28 September 2016.

Peragovics, F. (2013). Az első töri atlasz. http://peragraner.blogspot.hu/2013/10/az-elso-tori-atlasz.html. Accessed 10 October 2016.

Ruzsa, Á. (2008). Magyar iskolai földrajzi atlaszok tematikus térképeinek vizsgálata, MSc thesis. http://lazarus.elte.hu/hun/digkonyv/szakdolg/ruzs a/ruzsa.pdf. Accessed 2 October 2016. 